\title{
53 新しい消化管吻合器の使用経験
}

佐藤博信, 村山 公, 安楽直顕, 宋 圭男, 樑瀬知之, 田中和彦, 岩井重富, 田中 隆（日本大第三外科）

吻合器や縫合器の発達により消化管の手術手技安安 全でかつ容易になった。 また吻合器の各種消化管への 応用は，手術適応の拡大と手術侵襲の軽減をるたらし た．教室では昭和 53 年よりン連製の万能型消化管吻 合器を使用し始め, その後軸第曲型吻合器, EEA, CDEEA，PCEEA を使用してきたが今回アンビルへ ッドがチルトアップ可能な消化管吻合器が開発された のでその使用経験について報告する.

新しい消化管吻合器は PCEEA と同じ外観である が, 伆合器本体が $5 \mathrm{~cm}$ 長く, アンビルーッドの厚さ が若干薄くなり消化管への插入が従来の製品に比較し て容易に行觉る利点がある．使用方法はほぼ同様であ るが，消化管吻合後吻合器本体を拔去する際にウィン
グナットを回転するとアンビルへッドがチルトアップ して消化管からの抜けが容易になった。そのため従来 使用していたサイズょりる大きな口径の吻合器の使用 が可能となり，吻合口内腔も十分な広さを得ることが できる。実際には胃全摘術症例の再建術に利用してい るが，従来食道空腸吻合に $25 \mathrm{~mm}$ の外径の PCEEA を使用していたものが，本器を使用するようになって から $28 \mathrm{~mm}$ の外径のすのの使用が可能となった. 現 在までのところ絴合不全や術後狭窄などるみられず良 好な成績を得ている。

新た開発された消化管吻合器プレミアムプラス CEEAを消化管吻合に利用しているのでその使用法な らびに使用経験を検討し報告する.

\section{4 吸収性ステープル内蔵自動縫合器による消化管手術}

深瀬知之，佐藤博信，大塚善久，安楽值顕; 村山公， 田中 隆, 岩井重富 (日本大第三外科)

〔目的〕1994年より放射線透過性である吸収性ステー プルを内藏した自動縫合器「ポリGIA」が開発され たので，ステープルの吸収過程について実験的, 臨床 的に検討した。

[対象と方法]雑種成犬10頭を用いて，吸収性ステー プル内藏自動链合器による胃空腸吻合術を行い, 術後 1 ヶ月，2ヶ月， 3 ヶ月，4ヶ月， 4.5 ヶ月で再開腹 し，昒合部を切除摘出し，肉眼的観察と HE 染色によ る組織学的所見により検討した。

[結果](1)肉眼的には1ヶ月ではかなりのステープル が残存しているが，すでに変形は始まっていた， 2 ヶ 月目ではさらにステープルの吸収が進み，一部は完全 吸収され，部分的に小片を触知するのみであった， 3 ヶ月以降はステープルは全く触知せず，吻合部す完全 に治窇の状態であった。.(2)組織学的には 1 ヶ月目では ステープルが粘膜下層・筋層に多数残存していた. そ の周囲に組織球とリンパ球の漫潤が見られた。しかし 線維性俞合は認めた。 $2 \sim 3$ ヶ月目になると創傷は治
刑し，一部線維化の部位に小型の以上吸収され た）ステープルと組織球が見られた，4ヶ月目では小 さなステープルを一片認めるのみで， 4.5 月月目では 完全に吸収されていた（3)縫合不全等の合併症は 1 例 るなかった。

〔臨朱症例】1995年 8 月までに, 吸収性ステープル内 藏自動䉽合器を使用した消化管手術症例は合計11例で, 幽門側胃切除術 2 例, 胃部分切除術 3 例, 胃切開煡合 術 1 例, 胃空腸吻合術 2 例，小腸吻合術 1 例; 顕部食 道胃管吻合術 1 例, 回腸結腸吻合術 1 例であった. 胃 空腸吻合術を行った症例について術後内視鏡で経過を 観察したところ約 1.5 凡でステープルの変形が認め られた。

[結語] (1)実験的にはステープルの分解・吸収は術後 1 ヶ月目より始まり，4ヶ月目には完全に治瘾であっ た.（2)創傷治瘾の状態も良好で安全性も確認された。 (3)臨床的にも動物実験とほぼ同様な結果が得られた。 